\title{
Erratum to: Scheduling $U E T$-tasks on a star network: complexity and approximation
}

\author{
R. Giroudeau · J. C. König • B. Valery
}

Published online: 11 March 2011

(C) Springer-Verlag 2011

\section{Erratum to: 4OR-Q J Oper Res DOI 10.1007/s10288-010-0127-7}

In our paper, we made reference to Lahlou (1996) and we wrote (Sect. 2.3.1.) "the proof is not in the article". Actually, the proof is in Lahlou (1998).

\section{References}

Lahlou C (1996) Scheduling with unit processing and communication times on a ring network: approximation results. In: Proceedings of Europar, Springer-Verlag, pp 539-542

Lahlou C (1998) Ordonnancement dans les réseaux de processeurs: complexité et approximation. Ph.D. thesis, Université Paris VI

The online version of the original article can be found under doi:10.1007/s10288-010-0127-7.

R. Giroudeau $(\varangle) \cdot$ J. C. König · B. Valery

LIRMM, UMR 5506, 161 rue Ada, 34392, Montpellier Cedex 5, France

e-mail: rgirou@lirmm.fr

J. C. König

e-mail: konig@lirmm.fr

B. Valery

e-mail: valery@lirmm.fr 